\title{
AFFECTING FACTORS OF THE EXCLUSIVE BREASTFEEDING GIVING IN THE PUBLIC HEALTH CENTER WORKPLACE AT LINGKAR TIMUR IN BENGKULU CITY YEAR 2017
}

\author{
Elly Wahyuni, Serilaila, Donna Rahmiati \\ Jurusan Kebidanan Poltekkes Kemenkes Bengkulu, Jl.Indragiri No.3 Pd.Harapa \\ Bengkulu \\ Email : elly_bid@yahoo.com
}

\begin{abstract}
The coverage of exclusive breastfeeding in Indonesia is still low, in 2007 32\%, in $201227.1 \%$. Likewise Bengkulu Province, especially in East Circle Health Center $45.1 \%$ while the national target of $80 \%$. Many factors affect the exclusive breastfeeding of knowledge, age, motivation, employment and promotion of infant formula. The purpose of this study was to determine the factors that influence exclusive breastfeeding. This research was conducted by cross sectional method in mothers who have babies aged 7-12 months totaling 106 respondents (total sampling). Locations in Working Area Puskesmas Lingkar Timur on May-June 2017. Data were collected univariate, bivariate and multivariate analyzes using Chi Square test and multivariate logistic regression test. Results: a study of 106 mothers with babies $56.6 \%$ did not give exclusive breastfeeding, $57.5 \%$ less knowledge, $66.0 \%$ age $20-35$ years, $80.2 \%$ high motivation, $59.4 \%$ working mothers, $67,0 \%$ are not exposed to the promotion of formula milk. $(\mathrm{P}=0,00 \mathrm{RP}=5,60)$ and promotion of infant formula $(\mathrm{p}=0.00 \mathrm{RP}=8.20)$ is associated with exclusive breastfeeding, whereas the age variable $(\mathrm{p}=0.27 \mathrm{RP}=1.57)$ is not associated with exclusive breastfeeding. The most dominant factor is knowledge $(\mathrm{p}=0,00 \operatorname{Exp}(\mathrm{B})=15,909)$. Suggestion: It is expected to improve exclusive breastfeeding, health workers should establish breastfeeding mothers' classes with more intensive counseling. And the need for policies to provide appropriate sanctions against violations
\end{abstract}

Keywords: Exclusive Breastfeeding, Motivation, Knowledge Work, Age, Promotion of Formula Milk

\section{FAKTOR-FAKTOR YANG MEMPENGARUHI PEMBERIAN ASI EKSKLUSIF DI WILAYAH KERJA PUSKESMAS LINGKAR TIMUR KOTA BENGKULU TAHUN 2017}

\begin{abstract}
ABSTRAK
Cakupan ASI eksklusif di Indonesia masih rendah, pada tahun 2007 32\%, pada tahun 2012 27,1\%. Begitupun Provinsi Bengkulu, khususnya di Puskesmas Lingkar Timur 45,1\% sedangkan target nasional $80 \%$. Banyak faktor yang mempengaruhi pemberian ASI eksklusif yakni pengetahuan, usia, motivasi, pekerjaan dan promosi susu formula. Tujuan penelitian ini untuk mengetahui faktor-faktor yang mempengaruhi pemberian ASI eksklusif. Penelitian ini dilakukan dengan metode cross sectional pada ibu yang memiliki bayi usia 7-12 bulan berjumlah 106 responden (total sampling). Lokasi di Wilayah Kerja Puskesmas Lingkar Timur pada bulan MeiJuni 2017. Data yang dikumpulkan dianalisa secara univariat, bivariat dan multivariat menggunakan Chi Square test dan multivariat test regresi logistic. Hasil: penelitian dari 106 ibu yang memiliki bayi $56,6 \%$ tidak memberikan ASI eksklusif, 57,5\% pengetahuan kurang, 66,0\% usia 20-35 tahun, $80,2 \%$ motivasi tinggi, 59,4\% ibu bekerja, $67,0 \%$ tidak terpapar promosi susu formula. Variabel pengetahuan $(p=0,00 \mathrm{RP}=15,9)$, motivasi $(p=0.00 \mathrm{RP}=10,1)$, pekerjaan $(p=0,00$ $\mathrm{RP}=5,60)$ dan promosi susu formula $(p=0,00 \mathrm{RP}=8,20)$ berhubungan terhadap ASI eksklusif, sedangkan variabel usia $(p=0,27 \mathrm{RP}=1,57)$ tidak berhubungan dengan ASI eksklusif. Faktor yang paling dominan adalah pengetahuan $(p=0,00 \operatorname{Exp}(\mathrm{B})=15,909)$. Diharapkan untuk meningkatkan pemberian ASI eksklusif, petugas kesehatan hendaknya membentuk kelas ibu menyusui dengan penyuluhan yang lebih intensif. Serta diperlukannya kebijakan untuk memberikan sanksi yang sesuai terhadap pelanggaran.
\end{abstract}

Kata kunci : ASI Eksklusif, Motivasi, Pekerjaan Pengetahuan, Usia, Promosi Susu Formula. 


\section{PENDAHULUAN}

Angka Kematian Bayi (AKB) atau infant mortality rate merupakan indikator yang lazim digunakan untuk menentukan derajat kesehatan masyarakat, baik pada tatanan provinsi maupun nasional. AKB merujuk pada jumlah bayi yang meninggal pada fase antara kelahiran hingga bayi belum mencapai umur 1 tahun per 1000 kelahiran hidup. Saat ini angka kematian bayi di Indonesia masih tinggi dibandingkan dengan negara berkembang lainnya. Menurut World Health Organization (WHO) pada tahun 2013 Angka Kematian Bayi di dunia sebesar 34/1.000 kelahiran hidup. Berdasarkan survei SDKI (2012) AKB di Indonesia sebesar 32/1000 kelahiran hidup. Ini berarti di Indonesia, ditemukan 440 bayi yang meninggal setiap harinya.(1)

Penyebab kematian bayi di Indonesia disebabkan oleh infeksi neonatus yaitu sebesar (28\%), BBLR (26\%), asfiksia, (20\%), anomali congenital $(4 \%)$, diare $(3 \%)$, tetatus (2\%) dan (1\%) terkait dengan faktor gizi (WHO, 2010). Salah satu masalah dari kematian bayi tersebut, $2 / 3$ nya terkait dengan masalah gizi yang sebenarnya dapat dihindarkan. Dukungan nutrisi yang baik sangat penting pada masa neonatus. Air Susu Ibu (ASI) merupakan nutrisi terbaik bagi bayi sampai umur 6 bulan karena mempunyai komposisi gizi yang lengkap dan ideal untuk pertumbuhan dan perkembangan bayi. Hasil penelitian menunjukkan rata-rata pertambahan berat badan bayi per bulan dan total pertambahan berat badan selama 4 bulan pada kelompok bayi yang mendapat ASI Eksklusif lebih besar dari pada kelompok bayi yang tidak diberi ASI Eksklusif.(2)

ASI eksklusif merupakan makanan pertama, utama, dan terbaik bagi bayi yang bersifat ilmiah. ASI eksklusif diberikan pada bayi dari lahir hingga usia bayi 6 bulan tanpa tambahan makanan apapun, seperti susu formula, jeruk, madu, air teh dan air putih serta tanpa tambahan makanan padat seperti pisang, bubur susu, biscuit, bubur nasi dan nasi tim kecuali vitamin, mineral dan obat.(3) Berdasarkan hasil Survey Demografi Kesehatan Indonesia (SDKI) tahun 2007, cakupan pemberian ASI eksklusif di Indonesia masih sangat rendah yakni hanya sebesar $(32 \%)$ 
dan pada tahun 2012 cakupannya menurun menjadi $(27,1 \%)$. Capaian ini tentu saja belum mencapai target yang diharapkan yaitu sebesar $80 \% .(1)$

ASI eksklusif manfaatnya sangat baik untuk tumbuh kembang bayi, namun kenyataanya pemberian ASI eksklusif di Indonesia masih sangat rendah. Ibu seringkali memberikan makanan padat kepada bayi yang baru berumur beberapa hari atau beberapa minggu seperti memberikan nasi yang dihaluskan atau pisang. Hal ini mendukung pemberian makanan selain ASI di Indonesia yang telah diberikan berupa: susu formula sebesar 79,8\%, susu non formula 1,6\%, madu + air $14,3 \%$, air gula $4,1 \%$, air tajin $1,6 \%$, air kelapa $0,9 \%$, kopi $0,9 \%$, teh manis $1,2 \%$, air putih $13,2 \%$, bubur tepung saring $2,7 \%$, pisang halus $4,1 \%$, dan nasi dihaluskan 2,3\%.(4)

Apabila ASI eksklusif tidak diberikan pada bayi, dapat menyebabkan gangguan pencernaan atau diare yang secara tidak langsung berdampak terhadap penurunan berat badan. Hal ini dapat mengakibatkan kurang gizi pada anak, ini disebabkan karena sistem imun bayi belum sempurna dan pemberian makanan atau minuman selain ASI sama saja dengan membuka pintu gerbang masuknya berbagai jenis kuman.(4)

$$
\text { Faktor-faktor }
$$
yang mempengaruhi pemberian ASI eksklusif pada bayi usia 0-6 bulan yakni faktor usia, kondisi kesehatan, pengetahuan, motivasi, persepsi, pekerjaan, pendidikan, budaya, dukungan petugas kesehatan, dukungan orang terdekat, tempat bersalin dan promosi susu formula. Hasil penelitian yang dilakukan oleh Nurafifah (2007) menyatakan bahwa faktor yang paling dominan terjadinya kegagalan dalam pemberian ASI eksklusif adalah karena faktor pendorong yaitu pengetahuan dan motivasi ibu.(5)

Usia menjadi salah satu faktor yang dapat menimbulkan efek seorang ibu tidak memberikan ASI eksklusif. Sebagian besar ibu yang memberikan ASI Eksklusif umur 2030 tahun dimana pada umur tersebut adalah masa reproduksi sehat sehingga ibu mampu memecahkan masalah secara emosional, terutama dalam menghadapi kehamilan, 
persalinan, nifas dan merawat bayinya sendiri.(6)

Pekerjaan seharusnya tidak menjadi halangan untuk ibu tetap menyusui bayinya. Banyak para ibu bekerja yang merencanakan akan memberikan ASI jauh sebelum mereka hamil. Sayangnya, sejumlah penelitian mengungkapkan bahwa bekerja lebih dari 40 jam per minggu memiliki hubungan negatif secara signifikan terhadap durasi menyusui.(7)

Berdasarkan hasil penelitan yang dilakukan oleh Indrawati (2012) menunjukan hasil ada hubungan antara status pekerjaan ibu dengan pemberian ASI eksklusif pada bayi usia 0-6 bulan di BPM Ny. Etty Endrawati Kota Semarang. Pengetahuan juga menjadi salah satu faktor yang dapat menimbulkan motivasi seorang ibu dalam memberikan ASI eksklusif yakni semakin tinggi pengetahuan ibu tentang ASI eksklusif maka akan tinggi pula motivasi dalam memberikan ASI eksklusif.(8)

Motivasi merupakan dorongan yang timbul dari dalam diri seseorang yang secara sadar atau tidak sadar sehingga berperilaku untuk mencapai tujuan yang sesuai dengan kebutuhan. Hasil penelitian menemukan bahwa ada hubungan antara motivasi ibu dengan pemberian ASI eksklusif.(9)

Terdapatnya promosi susu formula di sarana pelayanan kesehatan khususnya di tempat persalinan mempunyai pengaruh langsung terhadap pemberian ASI Eksklusif hasil dalam penelitian didapatkan hasil ada hubungan antara promosi susu formula dengan pemberian ASI eksklusif. Di Kota Solok Provinsi Sumatera Barat.(10)

Menurut data profil Dinas Kesehatan Provinsi Bengkulu (2015) menunjukkan bayi yang diberikan ASI eksklusif sebanyak (52\%) dari 36.910 bayi. Di Kota Bengkulu hanya $(38 \%)$ dan merupakan cakupan terendah dari seluruh kabupaten yang ada di kota Bengkulu.(11) Menurut Dinkes Kota Bengkulu (2014) kota Bengkulu memiliki 20 Puskesmas dan cakupan ASI Eksklusif terendah pada tahun 2014 adalah di Puskesmas Basuki rahmat $(20,8 \%)$ dan cakupan tertinggi di Puskesmas Lingkar Timur $(85,4 \%)$, selanjutnya pada tahun 2015 cakupan ASI eksklusif 
terendah adalah di Puskesmas Bentiring (54,9\%) dan cakupan ASI eksklusif tertinggi di Puskesmas Padang Serai $(93,3 \%)$ di tahun 2015 cakupan ASI eksklusif di puskesmas Lingkar timur adalah $(83,5 \%)$. Pada tahun 2016 cakupan ASI eksklusif di Kota Bengkulu sebanyak $(61,4 \%)$ dan cakupan ASI eksklusif terendah di Puskesmas Jalan gedang yakni (33,3\%), Puskemas Lingkar Timur di tahun 2016 cakupan ASI eksklusif nya turun drastis menjadi $(45,1 \%)$ dan belum mencapai target nasional.(12)$$
\text { Berdasarkan Survey awal }
$$
tanggal 23 April 2017 yang dilakukan pada 10 ibu yang berkunjung ke posyandu untuk imunisasi bayinya berumur 7-12 bulan hanya 2 orang (20\%) yang memberikan ASI saja dari usia 0-6 bulan, sedangkan yang lainnya tidak memberikan ASI dengan alasan ibu tidak mengetahui apa itu ASI eksklusif serta manfaatnya untuk bayi, selain itu ibu bekerja di luar rumah sehingga tidak bisa menyusui bayinya setiap saat, ibu juga merasa pemberian ASI dari umur 0-6 bulan tidak cukup, untuk itu ibu terfikir untuk memberikan makanan tambahan sehingga ibu tidak termotivasi untuk memberikan ASI eksklusif kepada bayinya dan maraknya promosi susu formula melalui media membuat ibu termotivasi memberikan susu formula kepada bayinya sebelum umur 6 bulan.

\section{METODE}

Jenis penelitian yang dilakukan adalah Survey analitik dengan pendekatan cross sectional Pengambilan data dimulai dari tanggal 04 Mei sampai dengan 04 Juni 2017 di Wilayah Kerja Puskesmas Lingkar Timur Kota Bengkulu dengan menggunnakan data primer dan skunder, data skunder didapatkan dari buku register di ruang KIA dan data primer didapatkan dengan menyebarkan kuisioner.

Populasi dalam penelitian ini adalah seluruh ibu yang mempunyai bayi usia 7-12 bulan di Wilayah Kerja Puskesmas Lingkar Timur Kota Bengkulu tahun 2017 dengan jumlah populasi 106 ibu. Sampel dalam penelitian ini adalah total sampling.

\section{HASIL}


Tabel 1 Distribusi frekuensi pemberian ASI ekslusif, usia, pekerjaan,pengetahuan, motivasi dan promosi susu formula di Wilayah Kerja Puskesmas Lingkar Timur Kota Bengkulu Tahun 2017.

\begin{tabular}{lcc}
\hline \multicolumn{1}{c}{ Variabel } & $\begin{array}{c}\text { Frekuensi(n=106 } \\
\text { Orang) }\end{array}$ & $\mathbf{1 0 0 \%}$ \\
\hline ASI eksklusif & 60 & 56,6 \\
Tidak & 46 & 43,4 \\
Ya & 36 & 34,0 \\
\hline Usia & 70 & 66,0 \\
$<20$ th dan >35th & & \\
20-35 th & 63 & 59,4 \\
\hline Pekerjaan & 43 & 40,6 \\
Bekerja & & \\
Tidak bekerja & 61 & 57,5 \\
& 45 & 42,5 \\
\hline Pengetahuan & & 19,8 \\
Kurang & 21 & 80,2 \\
Baik & 85 & \\
\hline Motivasi & & 33,0 \\
Rendah & & 67,0 \\
Tinggi & 35 & \\
\hline Promosi susu formula & 71 & \\
Terpapar & & \\
Tidak terpapar & & \\
&
\end{tabular}

Analisis ini dilakukan untuk memperoleh gambaran distribusi frekuensi dari variabel independent yaitu pengetahuan, motivasi, usia, pekerjaan dan promosi susu formula, variabel dependent yaitu pemberian ASI eksklusif. Gambaran distribusi frekuensi dari variabel-variabel tersebut disajikan dalam bentuk tabel sebagai berikut:

\section{PEMBAHASAN}

\section{ASI Eksklusif}

Hasil penelitian (Tabel 1) didapatkan sebagian besar $(56,6 \%)$ ibu di Wilayah Kerja Puskesmas Lingkar Timur Kota Bengkulu tidak memberikan ASI eksklusif. Berdasarkan data dari Dinas Kesehatan Kota Bengkulu, cakupan pemberian ASI eksklusif di Kota Bengkulu hanya $61,4 \%$. Hasil penelitian ini menunjukkan bahwa cakupan pemberian ASI eksklusif di Wilayah Kerja Puskesmas Lingkar Timur di bawah cakupan pemberian 
ASI eksklusif di Kota Bengkulu sebesar 61,4\%. Berdasarkan data Riset Kesehatan Dasar tahun 2015, cakupan pemberian ASI eksklusif di Indonesia hanya $41 \%$.

ASI eksklusif merupakan makanan pertama, utama, dan terbaik bagi bayi. ASI eksklusif diberikan pada bayi dari lahir hingga usia bayi 6 bulan tanpa tambahan makanan apapun, seperti susu formula, jeruk, madu, air teh dan air putih serta tanpa tambahan makanan padat seperti pisang, bubur susu, biscuit, bubur nasi dan nasi tim kecuali vitamin, mineral dan obat.

Manfaat pemberian ASI dapat membantu bayi memulai kehidupannya dengan baik. Kolostrum, susu jolong, atau susu pertama mengandung antibodi yang kuat untuk mencegah infeksi dan membuat bayi menjadi kuat sehingga bayi memiliki sistem imun yang kebal dalam artian kebal terhadap penyakit.

\section{Hubungan usia dengan pemberian}

\section{ASI eksklusif.}

Berdasarkan hasil penelitian diketahui bahwa dari 106 responden hampir sebagian $(34.0 \%)$ dari ibu memiliki usia $<20$ tahun atau $>35$ tahun $(57,5 \%)$. Berdasarkan hasil

Tabel 2 Hasil Analisis Hubungan Usia dengan Pemberian ASI eksklusif di Wilayah Kerja Puskesmas Lingkar Timur Kota Bengkulu Tahun 2017.

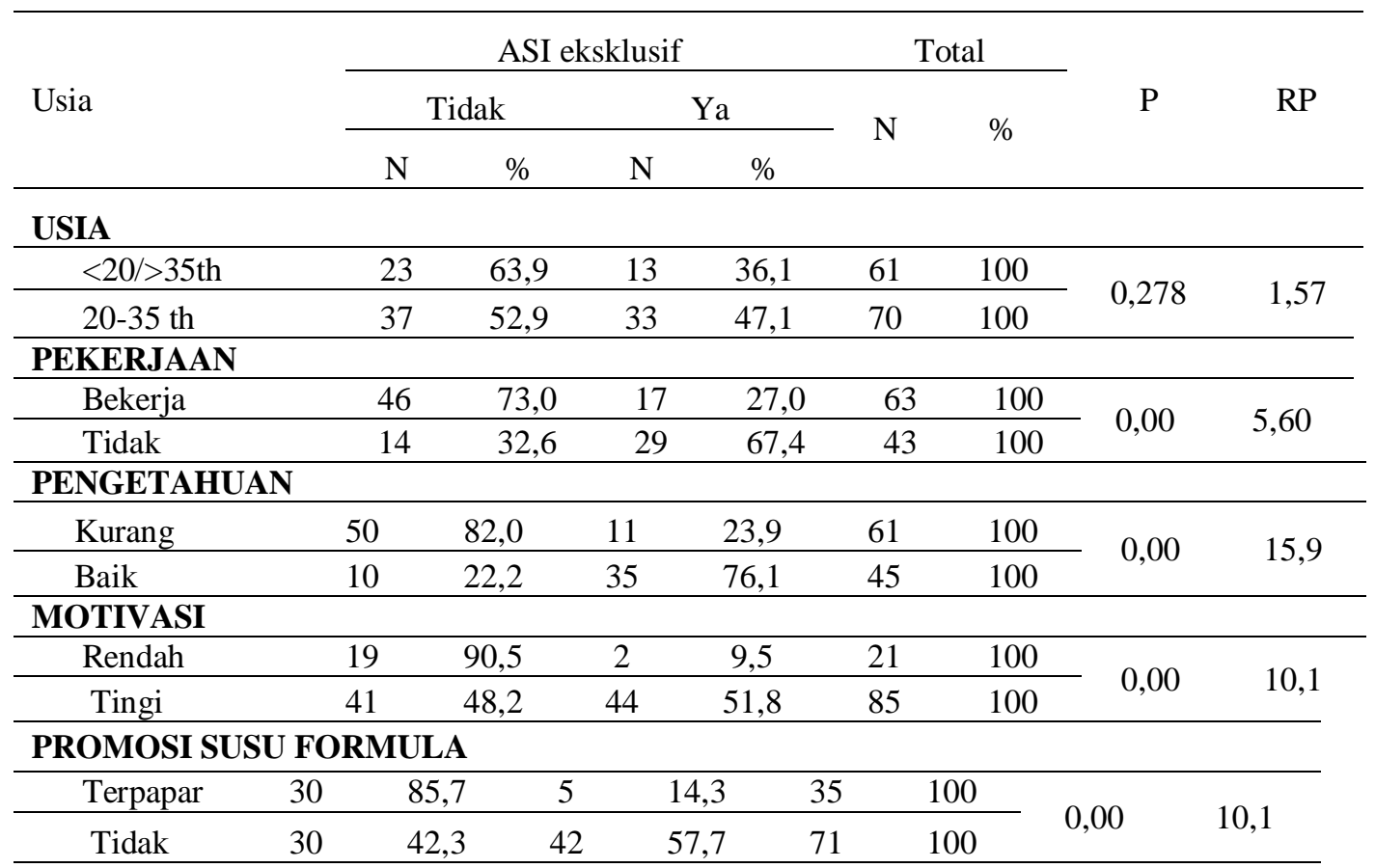


analisis bivariat menunjukkan bahwa ibu yang memiliki usia $<20$ tahun atau >35 tahun sebagian besar (63.9\%) tidak memberikan ASI eksklusif kepada bayinya. Dan tidak ada hubungan antara usia dengan pemberian ASI eksklusif dengan nilai $p=0.278$. (Tabel 2)

Usia dewasa dimana kemapuan motorik mencapai puncaknya yang mampu menyelesaikan diri dengan situasisituasi baru dan mampu mengatasi masalah besar, dalam kurun waktu reproduksi sehat dikenal usia aman untuk kehamilan, persalinan, dan menyusui adalah 20-35 tahun dan merupakan usia yang sangat baik dan sangat mendukung dalam pemberian ASI eksklusif. Usia yang kurang dari 20 tahun dianggap masih belum matang secara fisik, mental, dan psikologi dalam menghadapi kehamilan, persalinan,serta pemberian ASI.(13)

Hasil penelitian ini tidak sejalan dengan penelitian yang dilakukan oleh Pertiwi (2012) yang menunjukkan ada hubungan usia ibu dengan pemberian ASI eksklusif di kelurahan Kunciran Indah Tanggerang.

\section{Hubungan pekerjaan dengan pemberian ASI eksklusif}

Berdasarkan Tabel 2 dari 106 ibu yang mempunyai bayi terdapat sebagian besar $(59,4 \%)$ ibu yang bekerja. Berdasarkan analisis bivariat menunjukkan bahwa ibu yang bekerja sebagian besar (73.0\%) tidak memberikan ASI eksklusif. Hasil uji statistik didapatkan nilai $p=0.00$, hal ini berarti ada hubungan antara pekerjaan ibu dengan pemberian ASI eksklusif. Ibu yang bekerja berpeluang 5.60 kali untuk tidak memberikan ASI eksklusif dibandingkan dengan ibu yang tidak bekerja.

Hasil penelitian ini sesuai dengan teori yang dijelaskan oleh Notoatmodjo (2007) bahwa pekerjaan umumnya merupakan kejadian yang menyita waktu. Bekerja diluar rumah bagi seseorang akan menyita waktu sehingga akan mengganggu dalam pemberian ASI Ekslusif kepada bayinya. Pekerjaan seseorang akan berpengaruh terhadap kesehatan. Dikaitkan dengan pemberian ASI, pekerjaan akan mempunyai pengaruh terhadap ibu untuk memberikan ASI dengan baik sesuai dengan kebutuhannya.(14) 
Hasil penelitian ini sesuai dengan hasil penelitian Pusparini (2008) bahwa seringkali ibu-ibu yang bekerja mengalami dilema memberikan ASI Ekslusif pada bayinya dengan susu formula, hal ini merupakan suatu alasan klasik ibuibu pekerja.

Hasil penelitian ini juga didukung oleh hasil penelitian yang dilakukan oleh Mardeyanti (2007) bahwa Ibu yang bekerja lebih berisiko untuk tidak patuh dalam memberikan ASI eksklusif dibandingkan dengan ibu yang tidak bekerja.

Hasil penelitian ini sesuai dengan penelitian yang dilakukan oleh Rahayu dan Apriningrum (2014) yang menunjukkan hasil bahwa tidak ada hubungan antara pekerjaan ibu dengan pemberian ASI eksklusif pada karyawati Uniska di dengan nilai $p=0.66$

\section{Hubungan pengetahuan dengan pemberian ASI eksklusif}

Berdasarkan hasil penelitian diketahui bahwa dari 106 responden sebagian besar $(57,5 \%)$ ibu memiliki pengetahuan kurang. Berdasarkan hasil analisis bivariat menunjukkan bahwa terdapat hubungan antara pengetahuan dengan pemberian ASI eksklusif dengan nilai $p=0.00$. ibu yang mempunyai pengetahuan kurang berpeluang 15.9 kali tidak memberikan ASI eksklusif dibandingkan dengan ibu yang mempunyai pengetahuan baik.

Hasil penelitian (Tabel 2) ini sejalan dengan penelitian yang dilakukan oleh Widiyanto (2012) yang menunjukkan hasil bahwa ada hubungan antara pengetahuan ibu dengan pemberian ASI eksklusif di kabupaten Grobongan Jawa Tengah dengan nilai $p=0.00 .(15)$

Berdasarkan hasil penelitian ibu yang memiliki pengetahuan kurang hampir seluruh $(82.0 \%)$ tidak memberikan ASI eksklusif hal ini disebabkan terutama kurangnya pengetahuan tentang pengertian ASI eksklusif dan tekhnik menyusui. Hampir sebagian $(40,5 \%)$ dari ibu menjawab pertanyaan dengan tentang pengertian ASI eksklusif dengan benar dan hampir sebagian $(41,5 \%)$ dari ibu menjawab pertanyaan tentang tekhnik menyusui dengan benar.

Hasil penelitian didapatkan bahwa Ibu yang memiliki 
pengetahuan baik sebagian kecil (22.2\%) tidak memberikan ASI eksklusif karena adanya faktor-faktor lain yang mempengaruhi pelaksanaan pemeberian ASI. Hasil penelitian juga didapatkan ibu yang memiliki pengetahuan kurang sebagian kecil $(18,0 \%)$ memberikan ASI eksklusif dikarenakan kurangnya produksi sehingga ibu tidak memberikan ASI eksklusif kepada bayinya.

Hasil penelitian ini sesuai dengan penelitian yang dilakukan oleh Sariyanti (2015) yang menunjukkan bahwa terdapat hubungan yang bermakna antara pendidikan ibu, pengetahuan ibu dan sumber informasi dengan pemberian ASI Eksklusif.(6)

Hasil penelitian ini juga didukung oleh hasil penelitian Wahyuningrum (2007), yang mengatakan bahwa pengetahuan ibu tentang ASI Eksklusif dapat mempengaruhi ibu dalam memberikan ASI Eksklusif. Semakin baik pengetahuan Ibu tentang manfaat ASI Eksklusif, maka cendrung seorang ibu akan memberikan ASI Eksklusif pada anaknya. Begitu juga sebaliknya, semakin rendah pengetahuan ibu tentang manfaat ASI Eksklusif, maka semakin sedikit pula peluang ibu dalam memberikan ASI Eksklusif.

Hasil penelitian menunjukkan bahwa pengetahuan merupakan faktor yang paling mempengaruhi dalam pemberian ASI Eksklusif dan merupakan faktor yang paling dominan. Pengetahuan memiliki nilai $p=0,00$ dan nilai $\operatorname{Exp}(\mathrm{B})=15,909$ yang berararti bahwa ibu yang memiliki penegtahuan kurang berpeluang 15,909 kali berpeluang tidak memberikan ASI eksklusif di bandingkan ibu yang memiliki pengetahuan baik.

\section{Hubungan motivasi dengan} pemberian ASI eksklusif

Berdasarkan hasil penelitian diketahui bahwa dari 106 responden sebagian kecil $(19,8 \%)$ ibu memiliki motivasi rendah. Berdasarkan hasil penelitian ibu yang memiliki motivasi rendah hampir seluruh (90.5\%) tidak memberikan ASI eksklusif. Hal ini karenakan kurangnya motivasi ibu terutama tentang pemberian ASI saja pada bayi dan tentang pemenuhan kebutuhan ASI pada saat ibu bekerja. 
Tabel 3 Regresi Logistik Faktor-faktor yang mempengaruhi pemberian ASI eksklusif di Wilayah Kerja Puskesmas Lingkar Timur Kota Bengkulu Tahun 2017

\begin{tabular}{llllll}
\hline & \multirow{2}{c}{ Variabel } & \multirow{2}{*}{$\mathrm{P}$} & $\mathrm{EXP}(\mathrm{B})$ & \multicolumn{2}{c}{ 95\% C.I for } \\
\cline { 4 - 6 } & & & EXP(B) \\
\hline Step 1 & Pengetahuan & 0.000 & 15,909 & 6,097 & 41,514 \\
Step 2 & Pengetahuan & 0.000 & 16,345 & 5,618 & 47,561 \\
& $\begin{array}{l}\text { Promosi susu } \\
\text { formula }\end{array}$ & 0,001 & 8,540 & 2,405 & 30,332 \\
\hline
\end{tabular}

\begin{abstract}
Berdasarkan hasil analisis bivariat menunjukkan bahwa terdapat hubungan antara motivasi dengan pemberian ASI eksklusif dengan nilai $p=0.00$. ibu yang mempunyai motivasi rendah berpeluang 10,195 kali tidak memberikan ASI eksklusif dibandingkan dengan ibu yang mempunyai motivasi tinggi.
\end{abstract}

Hasil penelitian ini sejalan dengan penelitian yang dilakukakan oleh Nurkhayati (2014) yang menunjukkan bahwa ada hubungan antara pengetahuan ibu tentang ASI eksklusif dengan motivasi pemberian ASI eksklusif.(8)

Hasil penelitian ini juga sejalan dengan penelitian yang dilakukan oleh Listyaningrum dan Vidayanti (2016) yang menunjukkan hasil bahwa ada hubungan antara motivasi ibu dengan pemberian ASI eksklusif di PT. Globalindo Klaten
Jawa Tengah dengan nilai $p=0.03$.Ibu yang memiliki motivasi tinggi hampir sebagian (48.2\%) tidak memberikan ASI eksklusif dikarenakan kurangnya dukungan dari orang sekitar sehingga tidak ibu tidak termotivasi untuk memberikan ASI eksklusif kepada bayinya.

\section{Hubungan promosi susu formula} dengan pemberian ASI eksklusif

Berdasarkan hasil penelitian diketahui bahwa dari 106 responden hampir sebagian $(33,0 \%)$ terpapar promosi susu formula. Berdasarkan hasil penelitian menunjukkan bahwa ibu yang terpapar promosi susu formula hampir seluruh $(85,7 \%)$ tidak memberikan ASI eksklusif dikarenakan adanya anjuran dari tenaga kesehatan untuk menggunakan susu formula dan maraknya iklan susu formula di media cetak maupun elektronik 
sehingga ibu yang terpapar promosi susu formula tidak memberikan ASI eksklusif kepada bayinya.

Berdasarkan hasil penelitian juga menunjukkan bahwa Ibu yang tidak terpapar promosi susu formula hampir sebagian (42.3\%) tidak memberikan ASI eksklusif dikarenakan ASI ibu tidak keluar dan lecet pada payudara sehingga nyeri pada saat menyusui dan menyebabkan ibu tidak memberikan ASI eksklusif kepada bayinya.

Hasil penelitian ini sesuai dengan penelitian yang dilakukan oleh Julia (2014) yang menunjukkan bahwa ada hubungan antara promosi susu formula terhadap pemberian ASI eksklusif di Pagar Alam.

Berdasarkan hasil analisis bivariat (Tabel 3) menunjukkan bahwa terdapat hubungan antara promosi susu formula dengan pemberian ASI eksklusif dengan nilai $p=0.00$. Ibu yang terpapar promosi susu formula berpeluang 8,200 kali tidak memberikan ASI eksklusif dibandingkan dengan ibu yang tidak terpapar promosi susu formula. Hal ini sejalan dengan penelitian yang dilakukan oleh Ihsani (2011) didapatkan hasil ada hubungan antara promosi susu formula dengan pemberian ASI eksklusif. Di Kota Solok Provinsi Sumatera Barat dengan nilai $p=0,02$. Hasil penelitian menunjukkan bahwa promosi susu formula merupakan salah satu faktor yang mempengaruhi dalam pemberian ASI eksklusif dengan nilai $p=0,001$ dan nilai $\operatorname{Exp}(B)=8,540$ yang berarti ibu yang terpapar promosi susu formula berpeluang 8,540 kali tidak memberikan ASI eksklusif di bandingkan dengan ibu yang tidak terpapar promosi susu formula.

\section{SIMPULAN DAN SARAN}

Berdasarkan hasil penelitian tentang faktor-faktor yang mempengaruhi dalam pemberian ASI eksklusif di wilayah Kerja Puskesmas Lingkar Timur Kota Bengkulu Tahun 2017 adalah pekerjaan, pengetahuan, motivasi dalam pemberian ASI eksklusif dan promosi susu formula, sedangkan faktor yang tidak mempengaruhi pemberian ASI ekslusif adalah usia ibu. Faktor yang paling dominan yang mempengaruhi dalam pemberian ASI Eksklusif adalah pengetahuan, sedangkan motivasi, 
pekerjaan dan usia sebagai variabel konfounding.

Hendaknya petugas kesehatan mengadakan penyuluhan tentang ASI Eksklusif kepada ibu hamil maupun ibu menyusui, dengan membentuk kelas ibu menyusui (busui) dan juga penyampaian informasi dapat dilakukan dengan cara menyebarkan leaflet dan brosur tentang ASI eksklusif serta memberikan sanksi sesuai undang-undang kesehatan bagi tenaga kesehatan yang mempromosikan susu formula kepada ibu-ibu menyusui yang memiliki bayi 0-6 bulan.

\section{DAFTAR PUSTAKA}

1. Departemen Kesehatan Republik Indonesia. Survey Demografi Kesehatan Indonesia 2012. Jakarta; 2012

2. UNICEF Indonesia Penuntun Hidup Sehat. Kementrian Kesehatan Republik Indonesia, Jakarta; 2010

3. Prasetyono. Buku Pintar ASI eksklusif. Jogjakarta: Diva Pres; 2009

4. Kemenkes RI. Profil Kesehatan Indonesia Tahun 2012; 2013

5. Nurafifah, Dian. Faktor yang Berperan dalam Kegagalan Praktik Pemberian ASI Eksklusif; 2007

6. Sariyanti. Faktor-Faktor yang Berhubungan dalam Pemberian ASI Eksklusif di Wilayah Kerja Puskesmas Godean II Sleman
Yogyakarta. Naskah Publikasi Sekolah Tinggi Ilmu Kesehatan Aisyiyah Yogyakarta; 2015

7. Kemenkes. Dukung Ibu Bekerja, http://www.depkes.go.id. Diakses pada 16 maret 2017; 2015

8. Nurkhayati, Ayu. Hubungan antara Pengetahuan ibu tentang ASI Eksklusif dengan Motivasi Pemberian ASI Eksklusif. Naskah Publikasi Fakultas Psikologi Universitas Muhammadiyah Surakarta; 2014

9. Kartikasari, Indah dan Nurafifah. Hubungan Antara Motivasi dengan Pemberian ASI Eksklusif di Desa Balun Kecamatan Turi Kabupaten Lamongan. Surya, Vol 1, No 2, Maret 2009; 2009

10. Ihsani, Tien. Hubungan Promosi Susu Formula dan Faktor Lainnya dengan Pemberian ASI Eksklusif di Kota Solok Propinsi Sumatera Barat Pada Tahun 2011. Skripsi. Peminatan Kebidanan Komunitas, FKM UI. Depok; 2011

11. Dinas Kesehatan Provinsi Bengkulu. Profil Kesehatan dan Laporan Tahunan Dinas Kesehatan Bengkulu. Bengkulu; 2015

12. Dinas Kesehatan Kota Bengkulu. Profil Kesehatan dan Laporan TahunanDinas Kesehatan Kota Bengkulu. Bengkulu; 2014

13. Arini, H. Mengapa Seorang Ibu Harus Menyusui?. Yogyakarta. Flashbooks; 2012

14. Notoatmodjo, S. Pendidikan dan Perilaku Kesehatan. Jakarta :PT Rineka Cipta; 2007

15. Widiyanto, Subur. Hubungan Pendidikan dan Pengetahuan ibu tentang ASI Eksklusif dengan Sikap terhadap Pemberian ASI Eksklusif. Jurnal Kedokteran Muhammadiyah, Volume 1, Nomor 1, Tahun 2012. 